\title{
EMPIRICAL ANALYSIS OF THE ENVIRONMENTAL KUZNETS CURVE FOR ECONOMIC GROWTH AND CO 2 EMISSIONS IN NORTH AFRICAN COUNTRIES
}

\section{Mohammed Touitou}

Faculty of Economics and Business, University of Algiers 3, Algiers, Algeria e-mail: touitoutouitou@yahoo.fr

ORCID: 0000-0002-4442-7888

(C) 2021 Mohammed Touitou

This work is licensed under the Creative Commons Attribution-ShareAlike 4.0 International License. To view a copy of this license, visit http://creativecommons.org/licenses/by-sa/4.0/

Quote as: Touitou, M. (2021). Empirical analysis of the environmental Kuznets curve for economic growth and $\mathrm{CO}_{2}$ emissions in North African countries. Econometrics. Ekonometria. Advances in Applied Data Analysis, 25(2).

DOI: 10.15611/eada.2021.2.05

JEL Classification: O44, O10, Q57, C33

\begin{abstract}
This study aimed at examining the relation between economic growth and carbon dioxide $\left(\mathrm{CO}_{2}\right)$ emissions in North African countries in the period 2000-2018. To prove this, the author applied the OLS method of the two variables describing the Environmental Kuznets Curve: GDP per capita and $\mathrm{CO}_{2}$. The results show that GDP per capita reflects the influence of changes in the level of income on environmental pollution in five of the seven countries surveyed.
\end{abstract}

Keywords: $\mathrm{CO}_{2}$ emissions, economic growth, environment, panel cointegration approach.

\section{Introduction}

Environmental issues are the subject of much scientific research and are of constant concern to governments at the highest level around the world (Alkhathlan and Javid, 2013; Wang, Zhou, and Wang, 2011). In fact, the destruction of the ozone layer by the release into the atmosphere of greenhouse gases, including carbon dioxide $\left(\mathrm{CO}_{2}\right)$, constitutes the main threat to humanity. According to Stern (2007), it could cost the entire world's economy up to $\$ 550$ billion if real action is not taken. Due to the increasing use of energy, carbon dioxide emissions have increased dramatically over the past century, with a direct link to economic growth and development (Lau, Tan, Lee, and Mohamed, 2009; Soytas et al., 2009; Soytas, Sari, and Ewing, 2007). The relation between $\mathrm{CO}_{2}$ emissions, economic growth and energy consumption is therefore at the heart of current economic issues. 
The link between economic growth and the environment is a controversial issue. Traditional economic theory proposes a trade-off between economic growth and environmental quality (Lee, Chung, and Koo, 2005), where a destructive or mutually helpful relation can coexist. The first case leads to the hegemony of economic interests, causing the continuous destruction of the environment. At this point, countries superimpose the conditions required by the market in favour of increased production - although, according to Lee et al. (2005), greater growth in the scale of production causes greater pollution - and consumption, without adjusting the controls to the exploitation of raw materials and the emission of pollutants, thus putting stress on the environment in all economic systems at the global level (Munda, Nijkamp, and Rietveld, 1994). In the early stages of economic growth, degradation and pollution increase, although several empirical cases show that this trend can be reversed when the status of a developed country is achieved, thus benefiting the environment (Stern, 2004).

Since North Africa is a region made up of developing countries, it is intended to show this issue of destruction of the environment in this century (2000-2018) supported by the classical vision, where economic growth is considered subject to an increase in emissions of $\mathrm{CO}_{2}$ to the atmosphere, as one of the main causes of global climate change. The contribution of this article is an analysis of the current environmental situation in North African countries, based on the revised methodological scheme, carrying out an individualized treatment of the data for each country.

The environmental consequences of economic growth have been studied many times before, with varying results. The objective of this study is to investigate if there is a relation between economic growth and carbon dioxide $\left(\mathrm{CO}_{2}\right)$ emissions. Will a richer economy worsen the environmental quality even further due to increased emissions, or will an increase in per capita GDP not only increase the living standards, but also contribute to a better, less polluted planet?

The level of environmental degradation is quantified as per capita carbon dioxide $\left(\mathrm{CO}_{2}\right)$ emissions. It is well known that $\mathrm{CO}_{2}$ is one of the worst pollutants contributing to environmental issues (Houghton, 1996). Other pollutants causing environmental degradation are not included in this study; however, the theories used here could be applied for other pollutants as well. When measuring the economic status of a country, per capita gross domestic product (GDP) is normally used, as is this case. GDP is defined as the market value of all final goods and services produced in one period (Lequiller and Blades, 2006). Thus the research question of this study is as follows: is there a relation between per capita GDP and per capita $\mathrm{CO}_{2}$ emissions?

This paper is divided into five sections, including the introduction, and organized as follows. The first section presents a brief review of international empirical literature on the relation between $\mathrm{CO}_{2}$ emissions, energy consumption, and GDP. In the second, the methodology and data are shown. In the third section, the results 
of the panel cointegration tests are presented, in addition to the estimates. Finally, the fourth and last section presents the conclusions.

\section{Literature review}

The measurement of environmental quality has its origin in the environmental curve proposed by Simon Kuznets (1955); through which the relation between carbon dioxide $\left(\mathrm{CO}_{2}\right)$ emissions and urbanization can be shown. The main reason for this theory is to demonstrate how the growth of the urban population affects the environmental quality of the countries through the level of $\mathrm{CO}_{2}$ emissions. In this article, 141 countries were considered, classified according to their income, unlike most of the studies found which present analyses based on a single country.

Numerous researchers have studied the relation between energy consumption and GDP over the last thirty years, i.e. 1990-2020, however it is necessary to include $\mathrm{CO}_{2}$ emissions in this case, given the growing environmental concern, due to the problem of climate change that occurs worldwide. Some of the most relevant works on this topic during the first decade of this century, are reviewed below.

Since the study by Panayotou (1993), empirical work on the question of the relation between economic growth and the environment has continued to abound. Indeed, Panayotou (1993) attempted, through both theoretical and empirical analysis, to verify the hypothesis of the Kuznets environmental curve (CEK), and in addition broadened the debate by urging those interested in the issue of the economic growth-environment relation to deepen their research to better identify its nature.

Despite the important role that environmental policies play in maintaining a balance between the market and the environment, the experience of implementing these types of policies in developing countries has shown adverse results. According to Panayotou (1994), environmental policies applied in developing countries are divorced from economic policy and environmental sustainability, a condition that remains, according to the results of various empirical studies (Agras and Chapman, 1999; Bringezu, Schütz, Steger, and Baudisch, 2004; Dinda, 2004; Lee et al., 2005; Sayed, 2013), where the increase of certain pollutants - carbon dioxide and monoxide, nitrogen oxides and sulfur, among others - puts forward a hypothesis of the destructive economic growth of nature.

Therefore, it is suggested that failures in the management, design and implementation of environmental policies are evidenced in the increase in environmental degradation, which in turn is an inevitable result of economic growth (Yaduma, Kortelainen, and Wossink, 2013). Empirical evidence shows that this hypothesis is fulfilled in South American countries, where the constant increase in $\mathrm{CO}_{2}$ emissions, along with other pollutants, is largely explained by economic growth (Sayed, 2013; Suárez, 2011). In the academic environment this approach is represented through the Environmental Kuznets Curve (EKC), shown by an inverted U (Sayed, 2013), where the possible existence of a relation between environmental degradation 
and economic growth is demonstrated (Lee et al., 2005; Stern, 2004). In addition, the estimates made for $\mathrm{CO}_{2}$ emissions per capita (Apergis, 2016; Chng, Zhen Yang, 2019; Cho, Chu, and Yang, 2014; Farhani, Mrizak, Chaibi, and Rault, 2014; Galeotti, Lanza, and Pauli, 2006; Itkonen, 2010; Yang, Sun, Wang, and Li, 2015; Yin, Zheng, and Cheng, 2015; Shahbaz, Solarin, and Ozturk, 2016) indicate the presence of EKC in most of the countries analysed. However, Du et al. (2012) successfully rejected the Kuznets environmental curve (CEK) hypothesis. This result is confirmed by other authors, such as Chandran and Tang (2013), Saboori and Sulaiman (2013), Babu and Datta (2013), Zilio and Caraballo (2014), Özokcu and Özdemir (2017).

Cüneyt and Feyza (2018) studied the relation between $\mathrm{CO}_{2}$ emissions, GDP, energy consumption, trade openness, financial development and institutional quality for 151 countries in the period 1996-2010, using the pooled ordinary least squares method. The results confirm the EKC hypothesis, where the relation between income and environmental degradation is an inverted $U$ shape.

Işik, Ongan, and Özdemir, (2019) tested the EKC hypothesis for ten US states from 1980 to 2015, using an application of the heterogeneous panel estimation method. The results confirm the validity of the EKC hypothesis for Florida, Illinois, Michigan, New York, and Ohio. The results found negative impacts of fossil energy consumption on $\mathrm{CO}_{2}$ emission levels in Texas, while there is a positive influence of energy consumption on $\mathrm{CO}_{2}$ emissions in Florida but is lower compared to other states in the US.

Arifur et al. (2020) examined the EKC hypothesis for the BCIM-EC (BangladeshChina-India-Myanmar economic corridor) member countries under the Belt and Road Initiative (BRI) of China. The results confirm that the EKC hypothesis exists in India and China, as well as in Bangladesh and Myanmar with regard to disregarding breaks within the short term.

Zhang, Jihuan (2021) tested the Environmental Kuznets Curve Hypothesis on $\mathrm{CO}_{2}$ emissions for China in the period 1971- 2014, using ARDL model. The results indicate that there is an N-shaped relation between CO2 and GDP in the long run.

Cihan and Emrah (2021) tested the Environmental Kuznets Curve (EKC) in Australia using the Nonlinear ARDL Model with a Structural Break, for the period 1994 to 2014. The results confirm the validity of the EKC hypothesis.

\section{Data and methodology}

The testing of the EKC hypothesis for North African countries was carried out in this work through the annual time series dataset from 2000 to 2018. The data used came from the World Development Indicators (WDI). To measure environmental pollution, yearly $\mathrm{CO}_{2}$ per capita in metric tons is extracted from the WDI, which is calculated by the Carbon Dioxide Information Analysis Center (the $\mathrm{CO}_{2}$ series used in this study only include emissions from the burning of fossil fuels and the manufacture of cement). Annual real GDP per capita (constant 2010 US\$) from the 
WDI is used for the estimation as a proxy for income. Logarithms were applied to all variables to ameliorate heteroscedasticity issues.

Environmental management is essentially characterized by a technical, social, environmental, economic and political analysis (Munda et al., 1994). In the proposed case, an attempt was made to relate an economic component, growth, with an environmental one, i.e. $\mathrm{CO}_{2}$ emissions, whose causal effects were validated through the analysis of the time series for 2000-2018 for each one of the North African countries considered - (Algeria, Morocco, Tunisia, Libya, Egypt, Sudan and Western Sahara) through the application of the Ordinary Least Squares method (OLS). This research, being of a quantitative nature, is based on a positivist philosophy in which it is assumed that there are social factors with an objective reality different from individual beliefs, focusing more on explaining the causes of change in social factors (Firestone, 1987). The quantitative analysis in the proposed scheme aims to identify general propositions that perform reasonably well in a series of cases, even as they manage to explain each particular case well (Mitchell, 2003).

In this study the two variables usually employed in the representation of the Environmental Kuznets Curve were considered: GDP per capita as an independent variable, and $\mathrm{CO}_{2}$ emissions by energy sources expressed in metric tons per capita asa dependent variable, for the period from 2000 to 2018. In the case of GDP per capita, values expressed in dollars were taken at constant prices that have as the year reference 2010. A confidence level of $95 \%$ was assumed.

In the literature, various functions can be found that attempt to explain the relation between growth and environmental deterioration, the most common being the second-order polynomial, which demarcates a parable described by equation 1 (Dinda, 2004; Suárez, 2011)

$$
E D_{i t}=\alpha_{i}+\beta_{1} X_{i t}+\beta_{2} X_{i t}^{2}+\beta_{3} Y_{i t}+\varepsilon_{i t},
$$

where: $E D$ equivalent to the indicator of environmental deterioration $\left(\mathrm{CO}_{2}\right.$ emissions), $X$ is the GDP per capita, $i$ identifies the country, $t$ is the time value, $Y$ is any other indicator that accompanies economic growth (for example, population), $\varepsilon$ is the estimation error, $\alpha$ and $\beta$ are equivalent to the coefficients that are kept constant in the model.

In equation 2, an accepted variant is shown for the representation of the EKC (Agras and Chapman, 1999), where the data of the time series are smoothed through the natural logarithm

$$
\ln E D_{i t}=\alpha_{i}+\beta_{1} \ln X_{i t}+\beta_{2} \ln X_{i t}^{2}+\beta_{3} \ln Y_{i t}+\varepsilon_{i t} .
$$

The application of the OLS method through a system of simultaneous equations, one for each country, allows to identify those significant correlations under a statistically valid model, with conclusions of causality between the two variables 
considered in the study. The adjusted functions applied in the proposed analysis in this case are as follows

$$
\begin{gathered}
C O_{2 i t}=\alpha_{i}+\beta_{1} G D P P_{i t}+\beta_{2} G D P P_{i t}^{2}+\varepsilon_{i t}, \\
\ln C O_{2 i t}=\alpha_{i}+\beta_{1} \ln G D P P_{i t}+\beta_{2} \ln G D P P_{i t}^{2}+\varepsilon_{i t},
\end{gathered}
$$

where': $L C \mathrm{O}_{2 i t}-\mathrm{CO}_{2}$ emissions per capita; $L G D P P_{i t}-$ real GDP per capita; $L G D P P^{2}{ }_{i t}$ - real GDP per capita squared; $\varepsilon_{i t}$ - the error term.

\section{Results}

Table 1 shows the results obtained after applying the OLS method, considering equation 3. For the calculated parameter $t$ for a $\mathrm{P}<0.05$, the author marked with an asterisk those coefficients that were not robust in the model proposed. A positive relationship between $\mathrm{CO}_{2}$ emissions and GDP per capita can be observed in five of the seven countries analysed. The largest increases in $\mathrm{CO}_{2}$ emissions were found in Algeria and Morocco, with increases that remain between 0.06 and 0.14 metric tons per year, and whose trends show that these levels could continue to grow over time. In these countries, GDP per capita explains the increase in $\mathrm{CO}_{2}$ emissions.

Table 1. Results of the application of the OLS method cf. equation 3

\begin{tabular}{|l|c|c|c|c|}
\hline \multicolumn{1}{|c|}{ Country } & $\alpha$ & $\beta_{1}$ & $\beta_{2}$ & $\mathrm{R}^{2}$ \\
\hline Algeria & 4.8697 & -0.0007 & $5.27 \mathrm{e}-07$ & \\
& $(2.861)$ & $(-2.088)$ & $(2,495)$ & 0.9376 \\
\hline Morocco & -0.9893 & 0.0006 & $-7.86 \mathrm{e}-8$ & \\
& $(-0.1691)$ & $(0.5907)$ & $(-0.243)$ & 0.7685 \\
\hline Western Sahara & 3.1632 & -0.0004 & $3.26 \mathrm{e}-07$ & \\
& $(2.761)$ & $(-1.593)$ & $(1.748)$ & 0.5852 \\
\hline Sudan & -1.873 & 0.0007 & $-4.54 \mathrm{e}-07$ & \\
& $(-0.6325)$ & $(0.9784)$ & $(-0.715)$ & 0.7506 \\
\hline Egypt & 0.8043 & $-4.55 \mathrm{e}-04$ & $3.41 \mathrm{e}-08$ & \\
& $(2.985)$ & $(-0.6433)$ & $(0.6628)$ & $0.0411^{*}$ \\
\hline Libya & -4.4637 & 0.0012 & $-3.55 \mathrm{e}-07$ & \\
& $(-2.106)$ & $(0.0276)$ & $(-2.101)$ & 0.8716 \\
\hline Tunisia & 1.2087 & 0.0007 & -3.3254 & \\
& $(0.2107)$ & $(0.6794)$ & $(-0.5589)$ & $0.3512^{*}$ \\
\hline
\end{tabular}

() - standard error of estimation; * $\mathrm{R}^{2}$ is very low.

Source: author's elaboration.

${ }^{1}$ As is known, the parameters $\alpha_{i}, \beta_{1}, \beta_{2}$ represent the long-term elasticity of $\mathrm{CO}_{2}$ emissions with respect to $L G D P P_{i t}, L G D P P^{2}{ }_{i t}$ respectively. 
On the other hand, it can be observed that Tunisia and Egypt show non-significant correlations, indicating a case that is far from the traditional postulate of the EKC. Tunisia, in particular, presents a value of $\mathrm{R}^{2}$ that is not conclusive according to the function considered, originating value $t=2.363$ for $\mathrm{P}<0.05$. For both cases it is necessary to incorporate other indicators into the analysis to assess environmental deterioration and its relationship with economic growth.

Figure 1 shows the behaviour described by the function represented by the EKC in each of the cases analysed, highlighting the situation of Sudan and Libya, countries that could be contradicting the Kuznets hypothesis, which indicates that their development path has a positive proportional relation between $\mathrm{CO}_{2}$ emissions and economic growth via GDP per capita. In these countries, there is a reduction in $\mathrm{CO}_{2}$ levels from a higher GDP per capita increase of approximately US $\$ 9.600$ and US \$ 11.800 for Sudan and Libya, respectively.

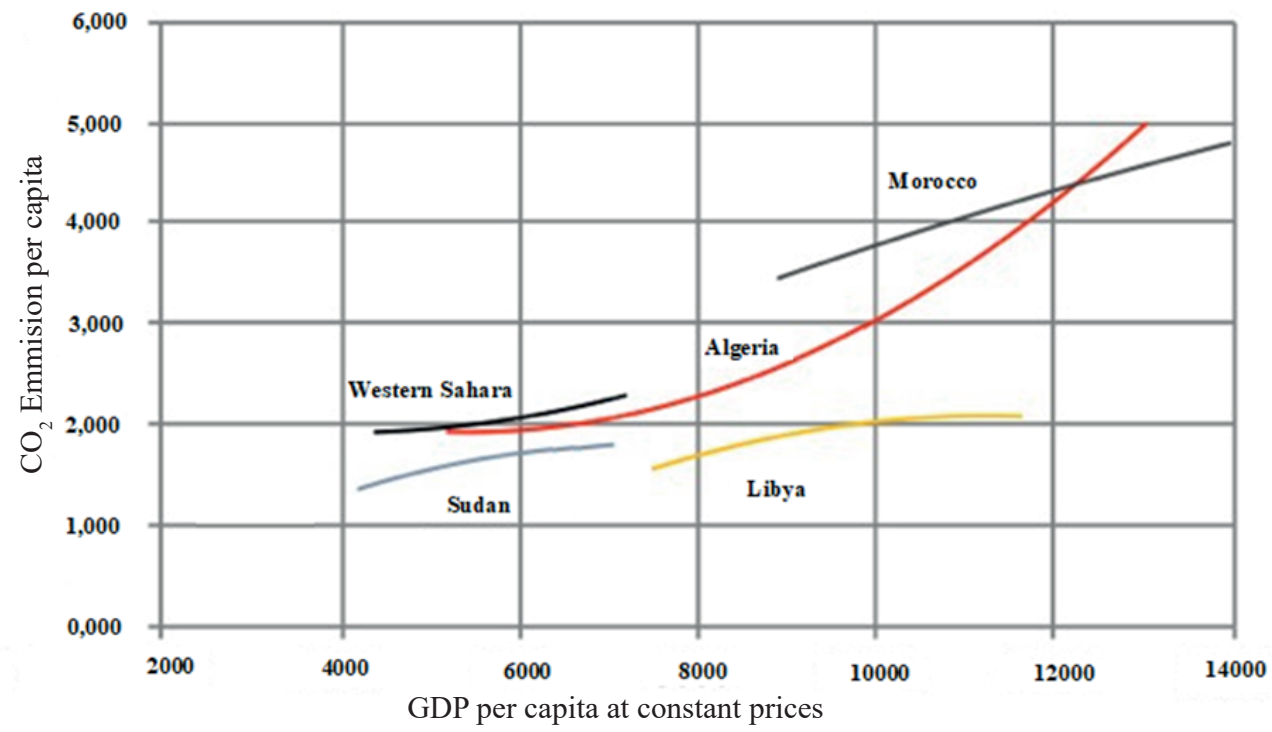

Fig. 1. $\mathrm{CO}_{2}$ emissions per capita and GDP per capita by country

Source: author's elaboration.

A situation similar to the previous model is observed with the application of equation 4 (Table 2), maintaining the same analysis parameters used in equation 3. The model is statistically validated using the Breusch-Pagan test on the variance of the disturbances. In the case of equation $3, \mathrm{x} 2=50.875$, with 36 degrees of freedom and $\mathrm{P}=0.0512$ were obtained. In equation $4, \mathrm{x} 2=49.858$, with 36 degrees of freedom, and $\mathrm{P}=0.0621$ were obtained. 
Table 2. Results of the application of the OLS method cf. equation 4

\begin{tabular}{|l|c|c|c|c|}
\hline \multicolumn{1}{|c|}{ Country } & $\alpha$ & $\beta_{1}$ & $\beta_{2}$ & $\mathrm{R}^{2}$ \\
\hline Algeria & $\begin{array}{c}169.856 \\
(2.573)\end{array}$ & $\begin{array}{c}-37.746 \\
(-2.718)\end{array}$ & $\begin{array}{c}2.241 \\
(2.682)\end{array}$ & 0.952 \\
\hline Morocco & $\begin{array}{c}-31.894 \\
(-0.272)\end{array}$ & $\begin{array}{c}6.362 \\
(0.227)\end{array}$ & $\begin{array}{c}-0.311 \\
(-0.2463)\end{array}$ & 0.781 \\
\hline Western Sahara & $\begin{array}{c}122.864 \\
(1.893)\end{array}$ & $\begin{array}{c}-25.831 \\
(-1.928)\end{array}$ & $\begin{array}{c}1.577 \\
(1.991)\end{array}$ & 0.579 \\
\hline Sudan & $\begin{array}{c}-79.849 \\
(-0.654)\end{array}$ & $\begin{array}{c}16.816 \\
(0.596)\end{array}$ & $\begin{array}{c}-0.944 \\
(-0.583)\end{array}$ & \multirow{2}{*}{0.792} \\
\hline Egypt & $\begin{array}{l}25.689 \\
(0.795)\end{array}$ & $\begin{array}{c}-6.224 \\
(-0.842)\end{array}$ & $\begin{array}{c}0.339 \\
(0.818)\end{array}$ & $0.061^{*}$ \\
\hline Libya & -159.629 & $\begin{array}{c}31.892 \\
(1.711)\end{array}$ & $\begin{array}{c}-1.772 \\
(-1.661)\end{array}$ & 0.861 \\
\hline Tunisia & $\begin{array}{c}-38.863) \\
(0.514)\end{array}$ & $\begin{array}{c}-0.517 \\
(-0.513)\end{array}$ & 0.371 \\
\hline
\end{tabular}

() - standard error of estimation; * $\mathrm{R}^{2}$ is very low.

Source: author's elaboration.

\section{Conclusions}

The main conclusion of the study mainly shows that GDP per capita reflects the influence of changes in the level of income on environmental pollution, contributing to the criticism in the sense that the social and economic system is inherent to the destruction of the environment (Levy, 1997).

The thirst for economic growth has inevitably increased the consumption of natural resources and the pressure to protect the environment (Yang, Yuan, and Sun, 2006), with North Africa being a palpable case of environmental deterioration in support of economic activity.

Just as with some developing countries in America and Asia, the problem in the North African region could derive from a failure in environmental policies and a commitment to conscious environmental management, with problems that could be extended to other indicators of environmental deterioration, such as deforestation and the emission of other pollutants (Chowdhury and Moran, 2012). In this study, the result was similar to that reached by Galindo (2010, p. 69), allowing for the conclusion that "the projections made allow us to assume that emissions per capita in the region will continue to increase in the form of an absolute convergence process ...".

Despite the above, the region could not be treated as a universal theoretical or empirical case, since there could be particular cases between countries where the effects could be contrary to those expected (Barrett, Bulte, Ferraro and Wunder, 2013), as is the case of Tunisia and Egypt. According to Zapata (2011, p. 73), this 
could be the opportunity to promote investments that catalyse and support "selective public spending, political reforms and changes in regulation", in order to reverse the trend in the increase in emissions of carbon dioxide. The degradation of the world's natural system requires an appropriate policy response (Barrett et al., 2013). For Yang et al. (2006), the empirical study shows that economic growth and environmental protection can be coordinated.

It is proposed to include in future research some additional variables related to other measures of pollution other than $\mathrm{CO}_{2}$ emissions, cf. Panayotou (1991), who states that not all the variables would have an explanation in GDP per capita.

\section{References}

Agras, J., and Chapman, D. (1999). Analysis: A dynamic approach to the Environmental Kuznets Curve hypothesis. Ecological Economics, 28(2), 267-277.

Alarco Tosoni, G. (2006). Economic growth and $\mathrm{CO}_{2}$ emissions from energy combustion in Mexico, 2005-2030.Economía mexicana Nueva Época, 15(2).

Alkhathlan K., and Javid, M. (2013). Energy consumption, carbon emissions and economic growth in Saudi Arabia: An aggregate and disaggregate analysis. Energy Policy, 62, pp. 1525-1532.

Apergis, N. (2016). Environmental Kuznets curves: New evidence on both panel and country-level $\mathrm{CO}_{2}$ emissions. Energy Economics, 54(C), 263-271.

Arifur et al. (2020). Evaluating the EKC Hypothesis for the BCIM-EC Member Countries under the Belt and Road Initiative. Sustainability, 12(4), 1478. doi: 10.3390/su12041478

Babu, S. S., and Datta, S. K. (2013). The relevance of the Environmental Kuznets Curve (EKC) in a framework of broad-based environmental degradation and modified measure of growth - a pooled data analysis. International Journal of Sustainable Development \& World Ecology, 20, 309-316.

Barrett, C., Bulte, E., Ferraro, P., and Wunder, S. (2013). Economic instruments for nature conservation. In D. Macdonald and K. Willis (Eds.), Key topics in conservation biology (First Edit., pp. 59-73). New York: John Wiley \& Sons, Ltd.

Bringezu, S., Schütz, H., Steger, S., and Baudisch, J. (2004). International comparison of resource use and its relation to economic growth. Ecological Economics, 51(1-2), 97-124. doi: 10.1016/ j.ecolecon.2004.04.010

Cancelo Márquez, M., and Díaz-Vázquez, M. (2002). CO emissions and economic growth in EU countries. Economic Studies of International Development. AEEADE, 1(2), 69-91.

Chandran, V. G. R., and Tang, C. F. (2013). The impacts of transport energy consumption, foreign direct investment and income on $\mathrm{CO}_{2}$ emissions in ASEAN-5 economies. Renewable and Sustainable Energy Reviews, 24(C), 445-453.

Chng, Zhen Yang (Rex) (2019). Environmental degradation and economics growth: Testing the environmental Kuznets Curve Hypothesis (EKC) in six ASEAN countries, Journal of Undergraduate Research at Minnesota State University, Mankato, 19 (Article 1).

Cho, C. H., Chu, Y. P., and Yang, H. Y. (2014). An Environmental Kuznets Curve for GHG emissions: A panel cointegration analysis. Energy Sources, Part B: Economics, Planning and Policy, 9(2), 120-129.

Cihan, Ö., and Emrah, B. (2021). The Environmental Kuznets Curve (EKC) in Australia: Evidence from Nonlinear ARDL Model with a Structural Break. Polish Journal of Environmental Studies, 30(3), 2245-2254. doi: https://doi.org/10.15244/pjoes/127555 
Cüneyt, K., and Feyza, B. (2018). Is there an environmental Kuznets Inverted-U Shaped Curve? Panoeconomicus, 65(1), 79-94.

Diaz-Vázquez, M., and Cancelo Márquez, M. (2009). $\mathrm{CO}_{2}$ and sulfur emissions and economic growth: An environmental Kuznets curve? Regional and Sectoral Economic Studies, 9(2).

Dinda, S. (2004). The Environmental Kuznets Curve hypothesis: A survey. Ecological Economics, 49(4), 431-455. doi:10.1016/j.ecolecon.2004.02.011

Farhani, S., Mrizak, S., Chaibi, A., and Rault, C. (2014). The Environmental Kuznets Curve and sustainability: A panel data analysis. Energy Policy, 71(C), 189-198.

Firestone, W. A. (1987). Meaning in method: The rhetoric of quantitative and qualitative research. Educational Researcher, 16(7), 16-21.

Galeotti, M., Lanza, A., and Pauli, F. (2006). Reassessing the Environmental Kuznets Curve for $\mathrm{CO}_{2}$ emissions: A robustness exercise. Ecological Economics, 57(1), 152-163

Galindo, L. 2010. The economics of climate change in Latin America and the Caribbean: Some stylized facts. Revista de La CEPAL, 100(Abril), 69-96.

Houghton, J. T. (1996). Climate change 1995: The science of climate change. Cambridge: Cambridge University Press.

Işık, C., Ongan, S., and Özdemir, D. (2019). Testing the EKC hypothesis for ten US states: An the application of heterogeneous panel estimation method. Environmental Science and Pollution Research, 26(11), 10846-10853.

Itkonen, J. (2010). Internal validity of estimating the carbon Kuznets curve by controlling for energy use (IFO Working Paper 95), Institute for Economic Research, University of Munich.

Jankilevich, N. S. (2003). World Summits on the Environment Stockholm, Rio and Johannesburg. 30 Years of Environmental History. Buenos Aires.

Lau, L. C., Tan, K. T., Lee, K. T., and Mohamed, A. R. (2009). A comparative study on the energy policies in Japan and Malaysia in fulfilling their nations' obligations towards the Kyoto Protocol. Energy Policy, 37(11), 4771-4778.

Levy, D. L. (1997). Business and international environmental treaties: Ozone depletion and climate change. California Management Review, 39(3),

Lee, H., Chung, R., and Koo, C. (2005). On the relationship between economic growth and environmental sustainability. In The 5th Ministerial Conference on Environment and Development in Asia and the Pacific (pp. 1-27). Seoul: Ministry of Environment.

Lequiller, F., and Blades, D. (2006). Understanding national accounts. Paris: OECD.

Marquetti, A., and Mendoza, G. (2013). Growth patterns and technical change in the production of a good and a bad product. Investigación Económica, 284(52), 57-82.

Mitchell, R. B. (2003). A quantitative approach to evaluating. A Quantitative Approach to Evaluating International Environmental Regimes (November 2002).

Munda, G., Nijkamp, P., and Rietveld, P. (1994). Qualitative multicriteria evaluation for environmental management. Ecological Economics, 10(2), 97-112. doi: 10.1016/0921-8009(94)90002-7

Özokcu, S., and Özdemir, Ö. (2017). Economic growth, energy, and the Environmental Kuznets Curve. Renewable and Sustainable Energy Reviews, 72, 639-647.

Panayotou, T. (1991). Economic growth and the environment. Cambridge.

Panayotou, T. (1993). Empirical tests and policy analysis of environmental degradation at different stages of economic development (Working Paper WP238), Technology and Employment Programme, International Labour Office, Geneva.

Panayotou, T. (1994). Economic instruments for environmental management and sustainable development. Nairobi.

Poudel, B., Paudel, K., and Bhattarai, K. (2009). Searching for an Environmental Kuznets Curve in carbon dioxide pollutant in Latin American countries. Journal of Agricultural and Applied Economics, 41(1),13-27. 
Roy Chowdhury, R., and Moran, E. F. (2012). Turning the curve: A critical review of Kuznets appro-aches. Applied Geography, 32(1), 3-11. doi:10.1016/j.apgeog.2010.07.004

Saboori, B. and Sulaiman, J. (2013). Environmental degradation, economic growth and energy consumption: Evidence of the Environmental Kuznets Curve in Malaysia. Energy Policy, 60(C), 892-905 .

Sayed, A. R. M. Al. (2013). The Environmental Kuznets Curve: Evidence from developed and developing economies. Applied Mathematical Sciences, 7(22), 1081-1092.

Shahbaz, M. A., Solarin, S. A., and Ozturk, I. (2016). The Environmental Kuznets Curve hypothesis and the role of globalization in selected African countries. Ecological Indicators, 67, 623-636.

Sotyas U., and Sari, R. (2009). Energy consumption, economic growth, and carbon emissions: Challenges faced by an EU candidate member. Ecological Economics, 68, 1667-1675.

Soytas U., Sari, R., and Ewing, T. (2007). Energy consumption, income and carbon emissions in the United States. Ecological Economics, 62(3-4), 482-489.

Stern, D. I. (2004). The rise and fall of the Environmental Kuznets Curve. World Development, 32(8), 1419-1439. doi: 10.1016/j.worlddev.2004.03.004

Suárez, G. A. (2011). Economic growth vs. environmental degradation: Is there an Environmental Kuznets Curve in Latin America and the Caribbean? Periodo 1970-2008. Flacso Ecuador.

Wang, S. S., Zhou, P., and Wang, W. Q. (2011). $\mathrm{CO}_{2}$ emissions, energy consumption and economic growth in China: A panel data analysis. Energy Policy, 39, 4870-4875.

Yaduma, N., Kortelainen, M., and Wossink, A. (2013). The Environmental Kuznets Curve at different levels of economic development: A counterfactual quantile regression analysis for $\mathrm{CO}_{2}$ emissions. Manchester.

Yang, G., Sun, T., Wang, J., and Li, X. (2015). Modeling the nexus between carbon dioxide emissions and economic growth. Energy Policy, 86(C), 164-177.

Yang, L., Yuan, S., and Sun, L. (2006). The relationships between economic growth and environmental pollution based on time series data: An empirical study of Zhejiang Province. Journal of Cambridge Studies, 7(1), 33-42.

Yin, J., Zheng, M., and Chen, J. (2015). The effects of environmental regulation and technical progress on the $\mathrm{CO}_{2}$ Kuznets curve: evidence from China. Energy Policy, 77(C), 97-108.

Zapata, C. (2011). The role of inclusive growth in the green economy in developing countries. Politica Ambiental, 8(Junio), 73-79.

Zhang, Jihuan. (2021). The Environmental Kuznets Curve hypothesis on $\mathrm{CO}_{2}$ emissions: Evidence for China. Journal of Risk and Financial Management, 14(93). https://doi.org/10.3390/jrfm14030093

Zilio, M., and Caraballo, M.A. (2014). The end of the carbon Kuznets curve? A semi-parametric analysis for Latin America and the Caribbean. El Trimestre Económico, lxxxi, (321), 241-270.

\section{ANALIZA EMPIRYCZNA ŚRODOWISKOWEJ KRZYWEJ KUZNETSA WZROSTU GOSPODARCZEGO I EMISJI CO, W KRAJACH AFRYKI PÓŁNOCNEJ}

Streszczenie: Celem pracy było zbadanie związku między wzrostem gospodarczym a emisją dwutlenku węgla $\left(\mathrm{CO}_{2}\right)$ w krajach Afryki Północnej w latach 2000-2018. Aby to udowodnić, autor zastosował metodę OLS dwóch zmiennych opisujących środowiskową krzywą Kuznetsa: PKB per capita i $\mathrm{CO}_{2}$. Wyniki pokazują, że PKB per capita odzwierciedla wpływ zmian poziomu dochodów na zanieczyszczenie środowiska w pięciu z siedmiu badanych krajów.

Słowa kluczowe: emisje $\mathrm{CO}_{2}$, wzrost gospodarczy, środowisko, podejście kointegracji paneli. 